the Arctic, making a total of forty-seven characteristic of open habitats.

3. Plants Characteristic of Other Habitats but frequently found in open areas in both north and south. Of these there are eight species, making a total of fifty-five which are to be found in open areas.

4. Marsh or 'Heath' Plants. Of these there are seven species.

The more important conclusions to be drawn from these statistics are as follows: an overwhelming majority of the sixty-two native British vascular plants which reach high latitudes grow chiefly in the absence of competition-both towards their northern limit where the vegetation is generally open and towards their southern limit where under natural conditions it is almost always closed. No fewer than forty-seven ( 75.8 per cent) are plants predominantly of open soil (or rock crevices, which are ecologically similar in that competition is generally lacking), another eight being frequently found in such situations both in the north and in the south (total 88.7 per cent).

Of the seven remaining plants (which are rarely if ever to be found in open areas in the British Isles) I have seen one (Eriophorum angustifolium) colonizing damp open soil in the Far North both in Spitsbergen and Ellesmere, and to the south in Iceland, Labrador and southern Greenland; the larger phase of temperate regions may well be taxonomically as well as ecologically distinct. Exactly the same remarks apply in the case of Calamagrostis neglecta when Devon Island is substituted for the more northern Ellesmere (where this species is not known to occur). Like Calamagrostis neglecta, two more of the five remaining 'marsh or heath' plants, namely, Rubus Chamcemorus and Tofieldia palustris, reach north of $75^{\circ}$ only as depauperated relics eking out a precarious existence in one or two localities in West Spitsbergen where the climate is much tempered by the Gulf Stream, while the remaining three also are characteristically more southern plants which merely straggle northwards in a few favourable healthy areas.

It may accordingly be said that truly arctic vascular plants are usually perennial dwarfs which can propagate vegetatively or flower and ripen seed in the short cool summer obtaining north of $75^{\circ}$, and can endure cold and rapid changes in water-relationships, but are unable to withstand competition. They flourish in the Far North where the communities are generally open; to the south they rather naturally persist chiefly where conditions prevent the growth of ranker dominants, and where the growing season is not too long and warm for their normal metabolism. Thus in the British Isles the majority are rare alpines of rock crevices or other 'open' habitats. It is without doubt only the persistence of such habitats in Britain which has allowed the survival (or perhaps in some cases recent introduction) of so considerable an arctic element in the British flora.

\footnotetext{
2 Proc. Linn. Soc., Session 151, 131 (1939).

2 Names and other details of the individual species and varieties concerned will be published in the Journal of Botany, 77 (September, 1939).
}

\title{
WILLIAM SMITH (I769-I839), THE FATHER OF ENGLISH GEOLOGY
}

$\mathrm{O}^{\mathrm{N}}$ Tugust 28, 1839, 'Strata' Smith, as he was familiarly known, died at the house of a friend in Northampton. He was on his way to a meeting of the British Association in Birmingham, to which he had been specially invited, but was taken ill before he could continue his journey. Thus passed away, at the age of seventy years, one of the greatest figures in British geology.

Smith's contributions to science are too well known to need more than brief mention here. After establishing that the different rock strata encountered in the course of his work as a land surveyor always occurred superposed in a particular order, he also discovered that individual strata could be recognized by the fossils they contained. He tested these fundamental observations in various parts of England and everywhere found support for his theory. His conclusions, and the extensive observations on which they were based, laid the foundations on which the whole structure of British stratigraphy is built. Further, as has been pointed out by Bather, the recognition of a regular succession of strata introduced the idea of relative time, and without this premiss, no proof of evolution is possible. Thus, it can fairly be claimed that Smith had an indirect though very important influence on the birth and development of the theory of evolution.

At an early date Smith formed the habit of recording his stratigraphical observations accurately on topographical maps. He evolved the idea of showing, by different colours, not only the areal distribution of the various strata, but also their structural relationship, that is, the vertical order 
in which they occur. Some of his early maps were exhibited to various societies, but the first to be published was his famous "Delineation of the Strata of England and Wales, with part of Scotland" (1815). This is a large-scale detailed map embodying the results of Smith's labours over a period of some twenty years, and is the first published geological map of England and Wales. Smith was thus one of the pioneers, if not the actual founder, of geological cartography in Britain.

In order to understand how Smith came to make his discoveries, and to appreciate their influence on contemporary thought, some knowledge of his early life is necessary. He came of farming stock, and, in 1787, at the age of eighteen years, he became assistant to a surveyor at Stowon-the-Wold, in Gloucestershire. Four years later, in 1791, he was entrusted with the survey of an estate in Somerset. Smith records that this was the year in which his first observations on stratigraphy were made, as a result of having been particularly impressed by the regular stratification of the Lias in the latter county. He continued to work in Somerset for some years, and during this period took the opportunity of acquainting himself with the principles of canal construction, a branch of engineering then much to the fore.

Afterwards he obtained an appointment as engineer to the projected Somerset Coal Canal, and Phillips, his nephew and biographer, says "it was the necessity of a close and accurate knowledge of the different sorts of rock, sand, and clay, which were to be cut through on the line of the canal, which led him to examine minutely and scrupulously into the distribution of the 'extran. eous fossils' which he had been in the habit of collecting". Work on the canal commenced in 1794 , and by 1799 , at the latest, Smith was convinced that different'strata in the neighbourhood of Bath could be identified by their fossils.

At this time geology had only just begun to establish itself as a separate science, and Smith's discovery was entirely novel, at all events in Great Britain. Yet he was able to support his conclusions with such strong evidence that he had no difficulty in converting to his views two enthusiastic and well-informed local geologists, the Rev. Benjamin Richardson and the Rev. Joseph Townsend. These gentlemen at once realized the importance of his discovery, and induced him to draw up a table of the strata around Bath, from the Coal Measures to the Chalk. This historically important document was copied and widely circulated both in Great Britain and abroad, but, unfortunately, it was not immediately published. As there was no formal publication of Smith's discoveries until a number of years later, his claim to be regarded as their author passed unrecognized except by his intimate friends, and it was long before he received the honours that were his due.

Meantime, Cuvier and Brogniart had begun to study the Tertiary deposits of the Paris Basin, and they arrived at the same conclusions as those which Smith had deduced from an examination of the English Jurassic rocks. Their results were published in 1808, and it is interesting that the same principles should have been discovered independently at approximately the same time in England and France. There is no doubt of Smith's priority, and it is clear that he achieved his results uninfluenced by the ideas of other workers. Whether the circulation of his views had had any influence on the Continent is not known.

Although Smith's claim to fame rests on his pioneer discoveries in geology, it should not be overlooked that he achieved distinction in his profession as surveyor and engineer. For many years his services were much in demand in an advisory capacity for problems of land drainage, schemes for protection from the inroads of the sea, water supply, and canal engineering. In fact, his first publication (1806) was an account of the draining of Brisley Bog, for which achievement he had received a medal from the Society of Arts. His application of geological principles to these problems undoubtedly contributed largely to his professional success. He was always alive to the economic possibilities of his knowledge of geology and his discoveries had an important bearing on, for example, the development of the British coal fields.

Rather surprisingly, Smith never became a member of the Geological Society of London, although he was resident in London for some years after its formation in 1807; and this Society was somewhat slow in affording him adequate recog. nition. In later life, however, it made him the first recipient of the Wollaston Medal. The announcement of this honour was made in Smith's presence at the first meeting of the British Association, held in York in 1831. He received the medal in 1832 from the hands of Sedgwick, who, in a laudatory address, referred to him as the "Father of English Geology". In 1835 Trinity College, Dublin, conferred on Smith an honorary LL.D.

It is satisfactory to be able to record that suitable honours were accorded to Smith during his lifetime. Later a monument to his memory was erected at Churchill, Oxfordshire, his birthplace; and memorial tablets have been placed on a house occupied by him at Midford, near Bath, and in Bath itself, on the former residence of the Rer. Joseph Townsend, in which he dictated his famous table of the strata near Bath.

V.A. E. 